\title{
Guarding the guards: Pluralist accountability for human rights violations by international organisations
}

\author{
Gisela Hirschmann ${ }^{*}$ \\ Institute for Political Science, Leiden University \\ ${ }^{*}$ Corresponding author. Email: g.k.hirschmann@fsw.leidenuniv.nl
}

(Received 17 June 2017; revised 25 May 2018; accepted 26 May 2018; first published online 24 July 2018)

\begin{abstract}
Human rights violations committed by international organisations (IOs) have raised demands that IOs should be held accountable for their decisions, policies, and actions. However, traditional forms of accountability have often failed in the context of global governance. This article introduces pluralist accountability as a form of accountability whereby third parties hold IOs and their implementing partners accountable for human rights violations. In pluralist accountability, third parties set the standards for IOs' actions in relation to human rights, review their behaviour and impose normative or material sanctions in case of misbehaviour. The article further reveals two conditions that foster the development of pluralist accountability, namely the competition among third parties and the degree of vulnerability of the implementing actors or the mandating authority with regard to human rights demands. This argument is illustrated with empirical insights from peace operations in Bosnia and Kosovo, which were accused of human trafficking and the violation of the rights of detainees.
\end{abstract}

Keywords: International Organisations; Human Rights; Accountability; Competition; Vulnerability; Peace Operations

\section{Introduction}

The policies and actions of international organisations (IOs) and their partners increasingly affect the lives and rights of individuals and may thus - unintentionally or purposefully - violate core international norms. ${ }^{1}$ Prominent cases are rights violations by United Nations (UN) peacekeepers and their cooperating partners, for example through the sexual exploitation and abuse of women and children, the organisation of human trafficking networks, or the failure to protect civilians from systematic killings. ${ }^{2}$ In other issue areas too, the impact of transnational authority on human rights has become obvious, such as in the implementation of economic programmes funded by the World Bank or of the austerity measures on the demand of the

\footnotetext{
${ }^{1}$ Monika Heupel and Michael Zürn (eds), Protecting the Individual from International Authority: Human Rights in International Organizations (Cambridge: Cambridge University Press, 2017); Guglielmo Verdirame, The UN and Human Rights: Who Guards the Guardians? (Cambridge: Cambridge University Press, 2011).

${ }^{2}$ Chiyuki Aoi, Cedric De Coning, and Ramesh Chandra Thakur (eds), Unintended Consequences of Peacekeeping Operations (Tokyo: United Nations University Press, 2007); Gisela Hirschmann, 'When protectors become perpetrators: United Nations Peacekeeping and the protection of physical integrity', in Heupel and Zürn (eds), Protecting the Individual from International Authority, pp. 157-85; Frédéric Mégret and Florian Hoffmann, 'The UN as a human rights violator? Some reflections on the United Nations changing human rights responsibilities', Human Rights Quarterly, 25:2 (2003), pp. 314-42; Sarah E. Mendelson, 'Barracks and brothels: Peacekeepers and human trafficking in the Balkans', Center for Strategic and International Studies Report (Washington 2005).
} 
European Union (EU) and the International Monetary Fund (IMF) in response to the economic and financial crisis. ${ }^{3}$

As a result of the growing concern about how to constrain the authority of IOs in order to protect human rights, accountability has become increasingly prominent in International Relations (IR) scholarship on international organisations. ${ }^{4}$ However, traditional accountability mechanisms, often derived from the national (democratic) context, are difficult to achieve in global governance. ${ }^{5}$ Instead, alternative forms of accountability have evolved that include a broader audience than just the institutions' member states as accountability holders, for example courts, other (regional) organisations or non-governmental organisations (NGOs). ${ }^{6}$ These forms of 'pluralist accountability', as I call it, have become a recent trend that deserves further attention in research.

So far, we know little about the nature of, the reasons for, and the effects of pluralist accountability. Therefore, this article establishes a conceptual framework for analysing the various forms of third-party accountability and asks under which conditions we can expect pluralist accountability to evolve in response to human rights violations by IOs and their partners. In particular, I argue that two factors facilitate the development of pluralist accountability. First, the competition for status and resources encourages third parties to act as accountability holders towards IOs and their implementing partners. This argument is based on the research on norm entrepreneurship and regime fragmentation, which has demonstrated the dynamics of competition among NGOs, between NGOs and intergovernmental organisations, and also between courts. ${ }^{7}$ Second, the implementing actors or the mandating authority are inclined to recognise third parties as accountability holders if they are socially vulnerable. This argument is derived from the research about states' compliance with human rights norms. ${ }^{8}$

In order to illustrate the argument, I provide empirical evidence from a comparative analysis of peace operations in Bosnia Herzegovina and Kosovo, which were implemented by a variety of different actors, such as regional organisations, national, or private actors. The selected cases cover operations that have been alleged to violate different human rights, such as the right to physical integrity, through sexual exploitation, abuse and human trafficking, or the right to due process of detainees. In response to these human rights violations, pluralist accountability evolved; however, not in all of the cases. The findings show that while a competitive environment

\footnotetext{
${ }^{3}$ Human Rights Watch, At Your Own Risk: Reprisals against Critics of World Bank Group Projects, report no. 978-16231-32491 (2015); Margot E. Salomon, 'Of austerity, human rights and international institutions', European Law Journal, 21:4 (2015), pp. 521-45.

${ }^{4}$ Jeremy M. Farrall, 'Rule of accountability or rule of law? Regulating the UN Security Council's accountability deficits', Journal of Conflict \& Security Law, 19:3 (2014), pp. 289-408; Mathias Koenig-Archibugi, 'Accountability', in Jacob K. Cogan, Ian Hurd, and Ian Johnstone (eds), Oxford Handbook of International Organizations (Oxford and New York: Oxford University Press, 2016).

${ }^{5}$ Simon Chesterman, 'UNaccountable? The United Nations, emergency powers, and the rule of law', Vanderbilt Journal of Transnational Law, 42:5 (2009), pp. 1509-41; Joseph S. Nye, 'Globalization's democratic deficit: How to make international institutions more accountable’, Foreign Affairs, 80:4 (2001), pp. 2-6.

${ }^{6}$ Ngiare Woods and Amrita Narlikar, 'Governance and the limits of accountability: the WTO, the IMF and the World Bank', International Social Science Journal, 53:170 (2001), pp. 569-83.

${ }^{7}$ Malte Brosig, 'The interplay of international institutions in Kosovo between convergence, confusion and niche capabilities', European Security, 20:2 (2011), pp. 185-204; Alexander Cooley and James Ron, 'The NGO scramble: Organizational insecurity and the political economy of transnational action', International Security, 27:1 (2002), pp. 5-39; Thomas Gehring and Benjamin Faude, 'A theory of emerging order within institutional complexes: How competition among regulatory international institutions leads to institutional adaptation and a division of labor', Review of International Organizations, 9:4 (2014), pp. 471-98; Frank Schimmelfennig, 'Competition and community: Constitutional courts, rhetorical action, and the institutionalization of human rights in the European Union', Journal of European Public Policy, 13:8 (2006), pp. 1247-64.

${ }^{8}$ Thomas Risse and Stephen C. Ropp, 'Introduction and overview', in Thomas Risse, Stephen C. Ropp and Kathryn Sikkink (eds), The Persistent Power of Human Rights. From Commitment to Compliance (Cambridge: Cambridge University Press, 2013), pp. 3-25.
} 
motivates third parties to act as accountability holders, the vulnerability of the implementing actors, and the mandating authority with regard to human rights demands is crucial for the recognition of pluralist accountability holders.

This article is structured as follows. In the next section, I present the empirical phenomenon of pluralist accountability, outline the theoretical concept used for the analysis, and situate it in the existing literature. Thereafter, I develop the theoretical framework for analysing the conditions for pluralist accountability in global governance. This is followed by an empirical illustration of pluralist accountability in response to human rights violations in peace operations in Bosnia Herzegovina and Kosovo. The concluding section summarises the main argument and discusses the generalisability and the implications of the findings for existing and future research.

\section{Pluralist accountability: Empirical phenomenon and concept}

IOs are increasingly scrutinised by a set of different actors with regard to their compliance with human rights. The European Court of Justice's Kadi decision of 2008 is an important example of how a regional court reviews an IO's impact on individual rights, in this case the UN Security Council's sanctions policy. ${ }^{9}$ A similar attempt was undertaken in 2013 by two non-governmental organisations (NGOs) who filed a complaint in the Southern District of New York Federal Court against the United Nations Stabilization Mission in Haiti (MINUSTAH). They claimed that the operation has caused serious harm to the Haitian population by spreading a cholera epidemic, which resulted in the deaths of at least 8,000 people. ${ }^{10}$ This growing trend of third parties, be it international or regional courts, international or regional organisations, or NGOs, to hold IOs accountable for human rights can also be identified in global economic governance and global health governance. ${ }^{11}$

This article puts forward the concept of pluralist accountability to conceptualise and explain this empirical phenomenon. Accountability is defined as the relationship between two actors by which one actor (the accountability holder) sets the standards for another actor's behaviour, provides a form of review, and sanctions the other (the accountee) if its actions deviate from the standards. Therefore, accountability is conceptualised in terms of three functions of standard-setting, monitoring, and sanctioning in line with existing research. ${ }^{12}$ Through standard-setting, the accountability holder prescribes the norms that the accountee should

\footnotetext{
${ }^{9}$ Case C-402/05 P and C-415/05, P. Kadi and Al Barakaat International Foundation v. Council and Commission, 2008, ECR I-6351. This judgement has been identified as an instance of 'global constitutionalism', and its implications have been widely discussed in the literature, for example Antje Wiener et al., 'Editorial. Global constitutionalism: Human rights, democracy and the rule of law', Global Constitutionalism, 1:1 (2012), pp. 1-15; Ramses A. Wessels, 'The Kadi Case: Towards a more substantive hierarchy in international law?', International Organizations Law Review, 5 (2008), pp. 323-7.

${ }^{10}$ See Georges v. United Nations, New York District Court, available at: $\{$ http://www.ijdh.org/wp-content/uploads/2013/10/ Georges-v.-United-Nations-Complaint.pdf\} accessed 31 January 2016.

${ }^{11}$ Woods and Narlikar, 'Governance and the limits of accountability'; Ilona Kickbusch, 'The development of international health policies - accountability intact?', Social Science \& Medicine, 51 (2000), pp. 979-89.

${ }^{12}$ Mark Bovens, 'Analysing and assessing accountability: a conceptual framework', European Law Journal, 13:4 (2007), pp. 447-68; Allen Buchanan and Robert O. Keohane, 'The legitimacy of global governance institutions', Ethics and International Affairs, 20:4 (2006), pp. 405-37; Erika De Wet, 'Holding international institutions accountable: the complementary role of non-judicial oversight mechanisms and judicial review', German Law Journal, 9 (2010), pp. 1987-2010; Ruth W. Grant and Robert O. Keohane, 'Accountability and abuses of power in world politics', American Political Science Review, 99:1 (2005), pp. 29-43; Alexandru Grigorescu, 'Horizontal accountability in intergovernmental organizations', Ethics \& International Affairs, 22:3 (2008), pp. 285-308. Other conceptualisations have defined accountability on the basis of components; see Jonathan G. Koppell, World Role: Accountability, Legitimacy, and the Design of Global Governance (Chicago and London: The University of Chicago Press, 2010); Jan Aart Scholte, 'Global governance, accountability and civil society', in Jan Aart Scholte (ed.), Building Global Democracy? Civil Society and Accountable Global Governance (Cambridge: Cambridge University Press, 2011), pp. 8-41.
} 
respect throughout the implementation. ${ }^{13}$ While a delegation contract usually prescribes the tasks to be fulfilled, holding someone accountable for human rights violations implies specifying which norms have to be respected in the course of the implementation. Monitoring defines activities that review whether these standards are respected in the implementing process. Hereby, the accountability holder establishes mechanisms for reporting and surveillance, such as spontaneous on-site visits. ${ }^{14}$ Accountability finally also implies that the accountability holder sanctions the accountee if the latter proves to disrespect the standards set. ${ }^{15}$ This can be normative-political sanctioning, through measures of 'naming and shaming', or material sanctioning, such as cutbacks in the budget, the revision, or ultimately the withdrawal of the agent's mandate. $^{16}$

Depending on which actor exercises the three core accountability functions of standardsetting, monitoring and sanctioning, we can distinguish different types of accountability. In vertical accountability, which has also been named internal or shareholder accountability, the accountability holder is the mandating authority. ${ }^{17}$ In contrast to that, pluralist accountability is characterised by third parties - such as international courts or regional organisations - who act as accountability holders. In pluralist accountability, the accountability holder is independent of the relationship between the mandating authority and the implementing actor. Pluralist accountability holders thus may be transnational, national, non-state or judicial actors who, individually or together, engage in standard-setting, monitoring and sanctioning. This type has also been characterised as external, diagonal, horizontal, or non-institutionalised forms of accountability. ${ }^{18}$ If third parties act on behalf of the 'real' accountability holder, that is, the affected people, this has been termed 'surrogate accountability'. ${ }^{19}$

What are the reasons for choosing the term 'pluralist' to describe standard-setting, monitoring, and sanctioning by third parties? First, the existing terms bear connotations that limit the analytical focus to a specific actor type. External accountability, as well as surrogate accountability, imply that affected people are directly involved in the accountability process, which is not always the case in the phenomenon this study intends to describe. Horizontal or diagonal accountability imply that the accountability holder is situated either on the same or on a different level in relation to the implementing actor, which poses limits to which actor can be regarded as an accountability holder. Second, the choice for the term pluralist accountability is inspired by recent debate in International Law scholarship on the relationship between constitutionalism and

\footnotetext{
${ }^{13}$ Michael Goodhart, 'Democratic accountability in global politics: Norms, not agents', Journal of Politics, 73:1 (2011), pp. 45-60.

${ }^{14}$ Darren G. Hawkins et al., 'Delegation under anarchy: States, international organizations, and principal-agent theory', in Darren G. Hawkins et al. (eds), Delegation and Agency in International Organizations (Cambridge: Cambridge University Press, 2006), pp. 3-38; Matthew D. McCubbins and Thomas Schwartz, 'Congressional oversight overlooked: Police patrols versus fire alarms', American Journal of Political Science, 28:1 (1984), pp. 165-79.

${ }^{15}$ Bovens, 'Analysing and assessing accountability'; Grant and Keohane, 'Accountability and abuses of power in world politics', p. 41.

${ }^{16}$ De Wet, 'Holding international institutions accountable', p. 856; Mark A. Pollack, 'Delegation, agency, and agenda setting in the European Community', International Organization, 51:1 (1997), pp. 99-134.

${ }^{17}$ Grigorescu, 'Horizontal accountability'; Robert O. Keohane, 'Global governance and democratic accountability', in David Held and Mathias Koenig-Archibugi (eds), Taming Globalization: Frontiers of Governance (Cambridge: Cambridge University Press, 2003), pp. 130-59; Nico Krisch, Beyond Constitutionalism: The Pluralist Structure of Postnational Law (Oxford: Oxford University Press, 2010); Thomas Risse, 'Transnational governance and legitimacy', in Arthur Benz and Yannis Papadopoulos (eds), Governance and Democracy: Comparing National, European, and International Perspectives (London and New York: Routledge, 2008), pp. 179-99.

${ }^{18}$ Bovens, 'Analysing and assessing accountability'; Abigail C. Deshman, 'Horizontal review between international organizations: Why, how, and who cares about corporate regulatory capture', European Journal of International Law, 22:4 (2011), pp. 1089-113; Krisch, Beyond Constitutionalism; Woods and Narlikar, 'Governance and the limits of accountability'.

${ }^{19}$ Jennifer Rubenstein, 'Accountability in an unequal world', Journal of Politics, 69:3 (2007), pp. 616-32.
} 
legal pluralism in light of an increasing fragmentation of international law. ${ }^{20}$ The concept of legal pluralism has been used in particular by scholars in the tradition of the 'New Haven School' to highlight the increasingly plural character of actors involved in law-making in contrast to the classical view that emphasised the role of sovereign states for the creation of law. ${ }^{21}$ Similar to the fragmented layers of international law, I consider the term 'pluralist accountability' to reflect best the fragmented and heterarchical character of accountability relationships of interest for this study. This concept allows us to analyse the accountability mechanisms enacted by a variety of actors, which would otherwise be overlooked when focusing on traditional conceptions of accountability. It is important to note, however, that the conceptual approach of this article presents a social-political understanding of accountability. It thus relies on a much broader conceptualisation than pure legal accountability, while it does also include legal aspects of accountability.

Traditional vertical accountability implies that standards-setting, monitoring, and sanctioning are undertaken by the delegating authority, that is, the IO's member states. Pluralist accountability, to the contrary, is characterised by standard-setting by external third parties outside of the original delegation relationship, for example, norm entrepreneurs ${ }^{22}$ or other standard-setting actors, such as NGOs, courts, or experts commissions. In the area of peacekeeping, the International Committee of the Red Cross, for example, has become a very important standard-setter with regard to the implementation of operations. In pluralist accountability, third parties empower themselves to collect information and monitor compliance of the agents' behaviour and provide a forum for review in which the accountee justifies its behaviour to the general public, other external actors, or the mandating authorities. Despite the fact that the most harmful and material sanctions, that is, the termination of the delegation relationship, can be exerted only in vertical accountability, material and normative sanctions can also be imposed by third parties. Pluralist legal theorists, for example, have highlighted the increasingly important role of courts for sanctioning. ${ }^{23}$

The ideal-type complete pluralist accountability as defined in this study encompasses all three functions of standard-setting, monitoring, and sanctioning exercised by third parties. Pluralist accountability remains incomplete if only one or two of the three functions are performed by the accountability holder. ${ }^{24}$ However, standard-setting, monitoring, and sanctioning do not have to be undertaken by one single third party; instead, these three functions can also be exercised by

\footnotetext{
${ }^{20}$ Pluralism has also been used by political theorists to describe the fragmentation of government in the struggle for power in democracies; see Robert A. Dahl, 'Pluralism revisited', Comparative Politics, 10:2 (1978), pp. 191-203. Taking this further, pluralist accountability focuses on the different actors involved in the struggle for control over power. In a very different way, theorists of the English School have referred to pluralism in the debate about the relationship between states in international society; see Hedley Bull, The Anarchical Society: A Study of Order in World Politics (London: Macmillan, 1977). The notion of pluralism here rejects an overarching normative framework such as human rights, in opposition to the concept of solidarism. The English School concept of pluralism thus assumes a plurality of normative standards that guide the society of states. The concept of pluralist accountability as it is used in this article differs from this because it implies a normative framework that is shared by the actors that are part of the accountability relationship.

${ }^{21}$ Krisch, Beyond Constitutionalism; William Burke-White, 'International legal pluralism', Michigan Journal of International Law, 25:4 (2004), pp. 963-79; Paul Schiff Berman, 'A pluralist approach to international law', Yale Journal of International Law, 32 (2007), pp. 301-29; Alec Stone Sweet, 'Constitutionalism, legal pluralism, and international regimes', Indiana Journal of Global Legal Studies, 16:2 (2009), pp. 621-45; Gunther Teubner, 'Global Bukinowa: Legal pluralism in the world society', in Gunther Teubner (ed.), Global Law Without a State (Brookfield: Dartmouth, 1996), pp. 3-28.

${ }^{22}$ Martha Finnemore and Kathryn Sikkink, 'International norm dynamics and political change', International Organization, 52:4 (1998), pp. 887-917.

${ }^{23}$ Karen J. Alter, The New Terrain of International Law: Courts, Politics, Rights (Princeton: Princeton University Press, 2014); Krisch, Beyond Constitutionalism.

${ }^{24}$ Note, however, that the evaluation of the strength or the quality of pluralist accountability is not the main object of this article. Conceptualisations of accountability that are based on components such as Scholte's will thus provide better frameworks to capture the variation in the degree of accountability (Scholte, 'Global governance, accountability and civil society', p. 17).
} 
several third parties who all act as accountability holders with regard to the same implementing actor. Of course, in reality, this ideal-type distinction is not always so clear-cut; the third parties that act outside the delegation relationship may be institutionally part of the mandating authority. These mixed forms can be described as 'delegated accountability', whereby the mandating authority delegates the exercise of core accountability functions to external third parties that may be pre-existing or even newly created for this purpose. Examples for delegated accountability are the World Bank Inspection Panel that reviews complaints from third parties regarding the Bank's projects relating to the Bank's own standards or the UN Office of Internal Oversight Services (OIOS), which is institutionally part of the UN Secretariat, yet can undertake independent monitoring, but has few independent sanctioning powers.

\section{Conditions for pluralist accountability in global governance}

Both vertical and delegated accountability have increasingly been studied, such as in recent studies on IOs' relations with non-state actors and the literature on judicalisation. ${ }^{25}$ In contrast to that, this article focuses on pluralist accountability. In order to understand the conditions for pluralist accountability, I rely on a theoretical framework that looks at both the 'supply side' and the 'demand side' of accountability. ${ }^{26}$ What are the 'push factors' that motivate external actors NGOs, courts, or regional intergovernmental organisations - to exercise accountability functions? What are the 'pull factors' that make the implementing actor or the mandating authority recognise them as accountability holders? I argue that a specific opportunity structure characterised by a competitive environment among third parties and certain characteristics of the implementing actor or the mandating authority, in particular their vulnerability regarding certain norms within a specific community, foster the development of pluralist accountability.

\section{Competition}

Research on norm entrepreneurship or regime fragmentation suggests that the particular competition that characterises the institutional context of third parties is an important condition for their participation in pluralist accountability. ${ }^{27}$ This competition among third parties can take place not only between NGOs, but also between NGOs and intergovernmental organisations or between courts, who all conceive themselves as guardians of human rights. ${ }^{28}$ Each organisation in a competitive environment strives to survive and to preserve its reputation by developing a 'niche capacity'. External third parties such as civil society, courts, or intergovernmental organisations consider themselves as accountability holders to compensate for lacking or ineffective vertical accountability. Regarding the competition between NGOs, this has been described as the 'independent global civil society effects' of human rights regimes. ${ }^{29}$ Exercising core accountability functions thus enables an organisation to develop a distinguished profile to separate itself from other concurring parties in the field of human rights. This process of profiling can result both from a rational cost-benefit analysis of how the exercise of accountability could possibly lead to greater material resources and from normative considerations that aim to promote human rights

\footnotetext{
${ }^{25}$ Jonas Tallberg et al., The Opening Up of International Organizations: Transnational Access in Global Governance (Cambridge: Cambridge University Press, 2013); Bernhard Zangl et al., 'Between law and politics: Explaining international dispute settlement behavior', European Journal of International Relations, 18:2 (2011), pp. 369-401.

${ }^{26}$ Jens Steffek, 'Explaining cooperation between IGOs and NGOs - push factors, pull factors, and the policy cycle', Review of International Studies, 39:4 (2013), pp. 993-1013.

${ }^{27}$ Brosig, 'The interplay of international institutions'; Cooley and Ron, 'The NGO scramble'; Gehring and Faude, 'A theory of emerging order'.

${ }^{28}$ Judith Kelley, 'The more the merrier? The effects of having multiple international election monitoring organizations', Perspectives on Politics, 7:1 (2009), pp. 59-64; Schimmelfennig, 'Competition and community'.

${ }^{29}$ Emily M. Hafner-Burton and Kiyoteru Tsutsui, 'Human rights in a globalizing world: the paradox of empty promises', American Journal of Sociology, 110:5 (2005), pp. 1373-411.
} 
in new areas. Thus, pluralist accountability is enacted if there is an institutional competition that motivates third parties to act as accountability holders (push factor).

This condition requires the following observable implications. First, we expect the institutional environment to be populated by actors who all conceive themselves as norm entrepreneurs in the transnational system and compete with each other about resources and reputation in the same issue area. Moreover, if there is another actor perceived to have an equal standing or if an actor has newly entered the issue area and still has to develop its standing, this can also be taken as an indicator for competition. These indicators can be found in the mandates of the potential accountability holders and also in their discourse directed towards perceived competitors or towards those providing them with resources.

\section{Vulnerability}

The research on accountability emphasises the importance of the mutual recognition between the accountability holder and the accountee. ${ }^{30}$ This implies that the standards set by the accountability holder are regarded as legitimate by the accountee, that the accountee subjects itself to a mechanism of review provided by the accountability holder and accepts the other's sanctioning authority. If we follow this line of reasoning, it is only logical to assume that the characteristics of the implementing agent have an influence on the accountability type. The crucial question therefore is: When do actors recognise third parties as relevant accountability holders and allow them to undertake standard-setting, monitoring, and sanctioning activities?

As the subject of recognition has not yet been treated by the research on accountability, I refer to an argument that has recently been made in the literature on compliance. Even if the underlying logic of action might be different, the conditions for compliance might also be applicable to the question when actors are more likely to recognise accountability holders. According to the authors of the 'spiral model', material and social vulnerability are two important scope conditions for actors to comply with human rights norms. ${ }^{31}$ Especially, social vulnerability is highly important as to when actors recognise third parties as accountability holders. Being socially vulnerable implies that the reputation and the social status of an actor within a specific community depend on its respect for certain norms. In contrast to that, an actor is less vulnerable when it can refer to a powerful counter-norm to justify its behaviour. ${ }^{32}$ Based on this argument, several authors explain how the US government was able to undermine the prescriptive status of the anti-torture norm regarding detainees during the Bush era after 2001 through 'discursive legitimation'. ${ }^{33}$ The US government was able to invoke a powerful counter-norm, namely the fight against terrorism, for the justification of torture of detainees in the denial phase of the spiral model and thus reduced its social vulnerability. ${ }^{34}$

Borrowing this argument, I posit that an actor's vulnerability or invulnerability influences whether it recognises third parties as accountability holders. Hence, as a second hypothesis, I assume that the implementing actor is more inclined to recognise external accountability holders if it is highly vulnerable in terms of its social status and human rights reputation (pull factor). Based on this logic, I expect the degree of vulnerability of the mandating authority in the delegation relationship fosters the development of pluralist accountability. If the principal, in particular the immediate principal, is vulnerable to human rights demands, it is more inclined to

\footnotetext{
${ }^{30}$ Grant and Keohane, 'Accountability and abuses of power in world politics'. This mutual recognition is crucial to distinguish accountability from protest or contestation and it is on that basis that the accountee subjects itself to review.

${ }^{31}$ Risse and Ropp, 'Introduction and overview', p. 20.

${ }^{32}$ Ibid., p. 21.

${ }^{33}$ Ian Hurd, 'Torture and the politics of legitimation in international law', in Andreas Follesdal, Johan K. Schaffer, and Geir Ulfstein (eds), The Legitimacy of International Human Rights Regimes (Cambridge: Cambridge University Press, 2013), pp. 165-89; Kathryn Sikkink, 'The United States and torture: Does the spiral model work?', in Risse, Ropp, and Sikkink (eds), The Persistent Power of Human Rights, pp. 145-63.

${ }^{34}$ Hurd, 'Torture and the politics of legitimation', p. 180; Sikkink, 'The United States and torture', p. 146.
} 
recognise third parties as external accountability holders for the implementing agents. This recognition can in turn indirectly influence the implementing actor's inclination to recognise external accountability holders.

A common strategy to decrease vulnerability in peacekeeping is to invoke a dilemma between security and human rights. In this context, human rights are conceptualised as private or individual interests that might oppose the general public interest of security and stability as promoted by the peace operation. The main observable implications for the construction of this dilemma are indicators that reflect arguments of exceptional circumstances and operational necessity, which limit the power of human rights within peacekeeping. ${ }^{35}$ Such dilemmas are not exclusive to the peacekeeping domain, but also exist in other issue areas, for example with regard to individual versus group rights or economic development and human rights.

\section{The argument and alternative explanations}

Both conditions have independent effects on the evolution of pluralist accountability. The competition among third parties influences the motivation of third parties to act as accountability holders. The vulnerability of the implementing actors instead fosters the recognition of pluralist accountability by the implementing actors and the mandating authority. The argument of this study thus contains a combined theoretical approach, considering both the 'demand side' in terms of the institutional opportunity structure and the 'supply side' in terms of specific actor characteristics. However, two potentially relevant alternative explanations from other important research strands need to be taken into consideration when examining the conditions for pluralist accountability.

First, we could also expect path dependence to explain the turn to pluralist accountability. ${ }^{36}$ Path dependence would imply that the principal's past decisions, for example when mandating the agent to implement a task, influence the nature of the accountability regime. Path dependent effects could also influence a third party's decision to act as an accountability holder. To control for possible path dependent effects, the analysis compares where the same institution acts as the mandating authority in the delegation relationship. I evaluate in each case through processtracing whether the prior accountability regime at the outset of the delegation contract has had an impact on the nature of the enacted accountability after human rights violations have become apparent.

Second, researchers have identified the rise of a general norm in terms of more democratic global governance. ${ }^{37}$ Based on this assessment, we should also expect a possible trend towards pluralist accountability mechanisms, where legitimate governance depends on the approval by transnational societal actors that share a common concern about compliance with human rights regarding the implementation of IO policies. ${ }^{38}$ In contrast to that, however, the same normative trend also has increased expectations that IOs ensure that they respect the rule of law. This, in

\footnotetext{
${ }^{35}$ Michael Kelly, 'The UN, security and human rights: Achieving a winning balance', in Nigel D. White and Dirk Klaasen (eds), The UN, Human Rights and Post-Conflict Situations (Manchester: Manchester University Press, 2005), pp. 118-48; Jan Wouters and Pierre Schmitt, 'Challenging acts of other United Nations' organs, subsidiary organs and officials', in August Reinisch (ed.), Challenging Acts of International Organizations Before National Courts (Oxford: Oxford University Press, 2010), pp. 77-110.

${ }^{36}$ Paul Pierson, 'Increasing returns, path dependence, and the study of politics', American Political Science Review, 94:2 (2000), pp. 251-67.

${ }^{37}$ Jens Steffek and Patricia Nanz, 'Emergent patterns of civil society participation in global and European governance', in Jens Steffek, Claudia Kissling, and Patricia Nanz (eds), Civil Society Participation in European and Global Governance: A Cure for the Democratic Deficit? (Basingstoke: Palgrave Macmillan, 2008), pp. 1-29; Jonas Tallberg and Anders Uhlin, 'Civil society and global democracy: an assessment', in Mathias Koenig-Archibugi and Raffaele Marchetti (eds), Global Democracy: Normative and Empirical Perspectives (Cambridge: Cambridge University Press, 2011), pp. 210-32.

${ }^{38}$ Valerie Sperling, Altered States: The Globalization of Accountability (Cambridge: Cambridge University Press, 2009), p. 321; United Nations Mission in Kosovo, UNMIK/REG/1999/1, 'UNMIK Regulation on the Authority of the Interim Administration' (1999).
} 
turn, results in the reinforcement of vertical accountability mechanisms in the context of a development towards a global administrative law. ${ }^{39}$ Therefore, while the concern for greater human rights protection certainly increases the demand for accountability in general, the norm for a more participatory global governance does not allow us to draw any unambiguous conclusions about the type of accountability and the particular conditions for pluralist accountability.

\section{Research design, case selection, and methods of data acquisition}

The field of peacekeeping is particularly apt to illustrate the complexity of today's global governance and the challenges for accountability. Peace operations today are characterised by multiple delegation steps that involve prolonged delegation and multiple parallel authorities. Moreover, peacekeeping operations involve both formal and informal acts of delegation, which is rather common in global governance. The privatisation of peacekeeping, as it happened in the operation in Bosnia, has increased since, and thus continuously poses challenges for accountability. ${ }^{40}$ Peacekeeping also very pointedly illustrates how global governance activities can infringe upon international norms, in particular through violating human rights.

As there is no systematic data ${ }^{41}$ on alternative accountability forms, I illustrate the argument with evidence from a qualitative comparative case study on the development of pluralist accountability in response to human rights violations in UN peace operations in Bosnia Herzegovina and Kosovo. Both operations mandated by the UN Security Council between 1996 and 2004 were accused of human rights violations committed by international staff, such as human trafficking and the violation of the right of detainees. ${ }^{42} \mathrm{I}$ hereby focus on the violation of rights that are no longer legally disputed, such as the right to physical integrity and the right to fair trial and due process, which should make accountability more likely to occur. Most importantly, these operations display a clear variance with regard to whether or not pluralist accountability evolved within the same country. The case selection thus follows the logic of variation on the dependent variable and juxtaposes two pairs of cases that vary with regard to the development of pluralist accountability. In Bosnia, pluralist accountability evolved in response to the involvement of private security actors and the UN-mandated International Police Task Force in human trafficking. In the same country, however, no pluralist accountability evolved in response to the violation of the rights of detainees by the NATO-led Stabilization Force (SFOR). In Kosovo, pluralist accountability can be identified in the case of detentions by the UN international administration (UNMIK), but not in the case of detentions by the NATO-led operation KFOR (Table 1).

Each case study contains an analysis of the accountability regime at the outset of the operation, in order to control for the potential influence of path dependency. I then examine each pair of cases through the method of process-tracing as to how the two conditions, that is, competition and vulnerability, influenced the evolution of pluralist accountability. The analysis of

\footnotetext{
${ }^{39}$ Simon Chesterman, 'Globalization rules: Accountability, power, and the prospects for global administrative law', Global Governance: A Review of Multilateralism and International Organizations, 14:1 (2008), pp. 39-52; Heupel and Zürn (eds), Protecting the Individual from International Authority; Benedict Kingsbury, Nico Krisch, and Richard B. Stewart, 'The emergence of global administrative law', Law and Contemporary Problems, 68:3/4 (2005), pp. 15-61.

${ }^{40}$ Ruta Nimkar, 'From Bosnia to Baghdad: the case for regulating private military and security companies', Journal of Public and International Affairs, 20:1 (2009), pp. 1-24; Louise Pingeot, Dangerous Partnership: Private Military \& Security Companies and the UN (New York: Global Policy Forum, 2012).

${ }^{41}$ For internal accountability, see Grigorescu, 'Horizontal accountability' or the Global Accountability Reports by One World Trust, available at: \{http://gaportal.org/global-indicators/global-accountability-report\} accessed 4 April 2017.

${ }^{42}$ Amnesty International, AI Index: EUR 05/002/2004, 'The Apparent Lack of Accountability of International PeaceKeeping Forces in Kosovo and Bosnia-Herzegovina' (2004).
} 
Table 1. Selected cases.

\begin{tabular}{lll}
\hline & Pluralist accountability & No pluralist accountability \\
\hline Bosnia & Case of human trafficking & Case of SFOR detentions \\
Kosovo & Case of UNMIK detentions & Case of KFOR detentions \\
\hline
\end{tabular}

causal mechanisms has been considered as particularly suitable for theory-building, in particular the development of middle-range theories. ${ }^{43}$ Regarding the first condition, competition, I examine how the process of profiling contributes to the rise of pluralist accountability. The analysis of the second condition, vulnerability, investigates how the process of recognition leads to the acceptance of pluralist accountability holders.

The empirical data are gathered from a variety of sources. Primary documents, made available by the different UN bodies, such as the UN Security Council and the Secretariat, and the individual operations, are one important source. They include official resolutions, meeting protocols, draft resolutions, reports, commissioned studies, and internal documents as far as access was provided. Further evidence is gathered from media and NGO reports. To complement this documentary analysis, I draw on a number of qualitative expert interviews with present and former UN staff, member states representatives and members from regional international organisations (for example, the Council of Europe), research institutes, and non-governmental organisations. Based on these various sources, this study provides an original comprehensive picture of accountability dynamics in peace operations.

\section{Accountability for human rights violations in the context of the operation in Bosnia: Human trafficking and detentions}

After the Dayton Peace Agreement of 1995, the UN Security Council mandated the UN Mission in Bosnia and Herzegovina (UNMIBH), an International Police Task Force (IPTF), and the NATO military operation (SFOR), to promote stability and human rights in the postconflict environment. ${ }^{44}$ Besides this complex network of implementing actors, the operation in Bosnia was the first peacekeeping operation to employ a security company, Dyncorp, to provide personnel for SFOR and the police force IPTF. ${ }^{45}$ With the arrival of peacekeeping forces, Bosnia turned into a flourishing business place for prostitution and trafficking within Europe. ${ }^{46} \mathrm{~A}$ significant number of IPTF monitors and SFOR private contractors frequented brothels where trafficked women were held, protected the owners from raids and sometimes even purchased trafficked women themselves on the pretext of freeing them. ${ }^{47}$ This stands in stark contrast to the

\footnotetext{
${ }^{43}$ Alexander L. George and Andrew Bennett, 'Process-tracing and historical explanations', in Alexander L. George and Andrew Bennett (eds), Case Studies and Theory Development in the Social Sciences (Cambridge: Harvard University Press, 2005), pp. 205-32; Peter Hedström and Petri Ylikoski, 'Causal mechanisms in the social sciences', Annual Review of Sociology, 36:1 (2010), pp. 49-67.

${ }^{44}$ United Nations Security Council, Resolution 1088(1996) (12 December 1996).

${ }^{45}$ Russell Buchan, Henry Jones, and Nigel D. White, 'The externalization of peacekeeping: Policy, responsibility, and accountability', Journal of International Peacekeeping, 15:3-4 (2011), pp. 281-315; Åse G. Østensen, 'In the business of peace: the political influence of private military and security companies on UN peacekeeping', International Peacekeeping, 20:1 (2013), pp. 33-47. In total, there were around 1,600-1,800 IPTF officers from over thirty countries deployed in Bosnia in 2002, one third of them were US police officers subcontracted by Dyncorp. See Colum Lynch, 'Misconduct, corruption by U. S. police mar Bosnia mission', UNClips (2001), available at: \{http://unclips.blogspot.de/2009/05/us-police-misconduct-marsbosnia.html\} accessed 31 January 2015.

${ }^{46}$ Human Rights Watch, Hopes Betrayed: Trafficking of Women and Girls to Post-Conflict Bosnia and Herzegovina for Forced Prostitution (New York: Human Rights Watch, 2002), p. 4.

${ }^{47}$ Human Rights Watch, Hopes Betrayed, pp. 49, 52, 62; Mendelson, 'Barracks and brothels'.
} 
UN's core objectives and the Security Council's mandates for the operations in Bosnia. In addition to that, the NATO-led operation SFOR was accused of violating the rights of detainees, in particular due process rights such as the right to counsel and independent review. ${ }^{48}$

The accountability framework at the outset of the operations was rather limited. The applicable UN Security Council resolutions 1035 and 1088 did not mention any human rights standards that should guide the implementing actors' behaviour. A Code of Conduct for international civilian police actors that had been introduced by the preceding operation UNPROFOR in 1993 did not play any role for the successor mission UNMIBH and its IPTF, let alone contractors. ${ }^{49}$ The Special Representative of the Secretary-General (SRSG) in Bosnia remained the most important channel for the Security Council to review and monitor IPTF behaviour. ${ }^{50}$ The possibilities for vertical sanctioning were limited by diplomatic and functional immunity regulations. ${ }^{51}$ First attempts to enhance vertical accountability were undertaken by two 'whistleblowers' within UNMIBH, who publicly exposed the behaviour of their colleagues and demonstrated how the mission leadership covered up their investigations. ${ }^{52}$ Senior officials within the IPTF and UNMIBH, however, asked the private security company to end their contracts and thus put vertical accountability to a halt.

Instead, pluralist accountability evolved with other actors outside of the original delegation relationship enacting accountability functions. The local office of the High Commissioner for Human Rights (OHCHR) in Bosnia set up a Joint Trafficking Project and established human rights standards for IPTF and SFOR personnel. ${ }^{53}$ It systematically collected information about the relationship between trafficking and the international presence and hired the 'whistleblower' Kathryn Bolkovac to investigate the involvement of IPTF officers. Most importantly, the office also engaged in sanctioning and supported Bolkovac in a court trial against Dyncorp. ${ }^{54}$ When the British court decided that the dismissal of Bolkovac was unlawful, the decision also publicly exposed the role of the UN leadership. ${ }^{55}$ This prompted further attempts of review by the US Congress through hearings and legislative acts. ${ }^{56}$

Acting as an accountability holder became an important mechanism of profiling for the OHCHR. The organisation resulted from the Vienna Conference on Human Rights in 1993, where NGOs lobbied for a more effective supranational institution monitoring the respect of states for human rights. Within the Geneva-based human rights institutions, however, the $\mathrm{OHCHR}$ as a new institution still had to find its niche, especially in light of the notorious budget

\footnotetext{
${ }^{48}$ Amnesty International, 'The Apparent lack of Accountability', p. 23.

${ }^{49}$ Duncan Chappell and John Evans, 'The role, preparation and performance of civilian police in United Nations peacekeeping operations', Criminal Law Forum, 10:2 (1999), pp. 171-271.

${ }^{50}$ Framework Agreement Annex 11, Article 2, available at: \{http://www.ohr.int/dpa/default.asp?content_id=380\} accessed 31 January 2015.

${ }^{51}$ See Annex 1A, Appendix B, Article 7 of the Framework Agreement, available at: $\{$ http://www.ohr.int/dpa/default.asp? content_id=380\} accessed 31 January 2015.

${ }^{52}$ Kathryn Bolkovac and Cari Lynn, The Whistleblower: Sex Trafficking, Military Contractors, and One Woman's Fight for Justice (London: Palgrave Macmillan, 2011).

${ }^{53}$ United Nations Secretary-General, UN doc. S/2000/1196, Report of the Secretary-General on the United Nations Interim Administration Mission in Kosovo (15 December 2000), para. 26.

${ }^{54}$ Bolkovac and Lynn, The Whistleblower, p. 211.

${ }^{55}$ The court stated that the failure of the UN administration and the IPTF to 'take an adequate grip on the situation and do something about it' was of an 'exceptionally serious nature' (UK Employment Tribunal, Bolkovac v. Dyncorp, case no. 3102729/01, Reserved Decision (1 July 2002), para. 38).

${ }^{56}$ Hearing before the Subcommittee on International Operations and Human Rights of the Committee on International Relations of the House of Representatives, 107th Congress, 24 April 2002, serial no. 107 85, available at: \{http://commdocs. house.gov/committees/intlrel/hfa78948.000/hfa78948_0f.htm \} accessed 31 January 2015; United States Department of Defense, 'Assessment of DoD Efforts to Combat Trafficking in Persons. Phase II - Bosnia-Herzegovina and Kosovo', Office of the Inspector General, case no. H03L88433128 (8 December 2003).
} 
and personnel shortages that accompanied the office from the beginning. ${ }^{57}$ Concurring institutions were, in particular, the human rights offices within individual peace operations and the International Organization for Migration (IOM).

Despite the presence of a human rights office within UNMIBH, the OHCHR also maintained a separate office in Bosnia. This parallel maintenance of OHCHR field offices and human rights offices in peace operations has often raised concerns about efficiency. Later initiatives sought to integrate the human rights offices in the different UN field presences. ${ }^{58}$ This separate mandate, however, enabled the OHCHR field office to act as an independent accountability holder. It could thus monitor the UN peacekeeping presence and report directly to the headquarters in Geneva without having to subordinate itself to the UNMIBH leadership. Acting as an independent monitoring body, the OHCHR field offices could demonstrate their relevance and even provide the Geneva 'human rights branch' with more leverage and a distinct profile vis-à-vis the New York peacekeeping department.

Competition also took place between the OHCHR and the IOM, as the latter already had the issue of human trafficking in its portfolio, and became particularly strong at the headquarters level in Geneva. ${ }^{59}$ In order to outline its distinctive profile, the OHCHR adopted a human rights based approach to distance itself from the IOM's focus on the repatriation of trafficking victims. The High Commissioner Robinson supported the local Bosnian office with a trust fund, to 'provide emergency support to trafficked women as well as to provide grants to local NGOs working in this area', which exactly characterised what the IOM was also doing in Bosnia. Robinson further strongly encouraged the office in Bosnia to expose the involvement of IPTF and UNMIBH members in human trafficking. ${ }^{60}$ In light of this institutional competition, the office in Bosnia was eager to demonstrate that its role in the fight against human trafficking was more important and more successful than what was being done by the IOM. ${ }^{61}$ By setting standards for international personnel and monitoring their compliance, the OHCHR thus developed a distinct profile as an accountability holder with a core focus on human rights that distinguished itself from the IOM.

While the competitive environment was important for the rise of accountability holders, the vulnerability of the implementing actors and the mandating authority with regard to human rights demands was crucial for the recognition of pluralist accountability holders. Especially the vulnerability of the IPTF and the UN as a whole was particularly high, as the UN's reputation in Bosnia had already suffered because of UNPROFOR's failure to protect civilians from the massacre in Srebrenica. Vis-à-vis the Bosnian police forces, IPTF officers were expected to act as role models in terms of their respect for human rights. ${ }^{62}$ Despite the UN's strategy to decrease its vulnerability by covering up and blame-shifting, this was finally also recognised by the UN itself: 'Peacekeepers' use of trafficking victims for sexual and other services has been a source of major embarrassment and political damage to U.N. PKOs [... and ] can taint entire missions. ${ }^{63}$

\footnotetext{
${ }^{57}$ Mary Robinson, 'Realizing Human Rights', Romanes Lecture, Oxford University (11 November 1997), available at: \{http://www.un.org/rights/50/dpi1938.htm\} accessed 31 January 2015.

${ }^{58}$ Andrew Clapham, 'The UN High Commissioner for Human Rights: Achievements and Frustrations', paper presented at the 'Symposium on the United Nations High Commissioner for Human Rights: The First Ten Years of the Office, and the Next', Columbia University Law School, New York (17-18 February 2003), available at: \{http://www2.law.columbia.edu/hri/ symposium/ClaphamPaper.htm\#_ftnref1\} accessed 31 January 2015.

${ }^{59}$ Carolina Wennerholm and Eva Zillén, 'IOM Regional Counter-trafficking Programme in the Western Balkans', SIDA Evaluation 03/37, Swedish International Development Cooperation Agency (2003), p. 66.

${ }^{60}$ Author's telephone interview with Madeleine Rees, 14 September 2012.

${ }^{61}$ Madeleine Rees, 'The Gendered Dimensions of Sex Trafficking: Freeman Spogli Institute for International Studies', CDDRL Working Papers no. 7 (2012), available at: \{http://iis-db.stanford.edu/pubs/23758/Rees_06_19_12.pdf\} accessed 31 January 2015.

${ }^{62}$ Human Rights Watch, Hopes Betrayed, pp. 2, 9.

${ }^{63}$ United Nations Department of Peacekeeping Operations, Best Practices Unit, Human Trafficking Resource Package (United Nations: New York, 2004), p. 23.
} 
In contrast to the case of human trafficking, pluralist accountability failed to evolve in response to allegations of torture and the violation of the right of due process of detainees by SFOR. Some attempts at standard-setting and monitoring were undertaken by NGOs and the Ombudsman for Human Rights in Bosnia. ${ }^{64}$ In addition to that, the Bosnian Human Rights Chamber, the Constitutional Court, and the Bosnian Supreme Court issued decisions in which they sanctioned the detention practices of SFOR, even if SFOR was not the appellant of the court file. ${ }^{65}$ However, SFOR for the most part simply ignored the domestic legal sanctioning exercised by Bosnian courts and continued its detention practices without modification. ${ }^{66}$

Why did pluralist accountability fail to evolve in the case of detentions by SFOR? First, there were no concurring transnational non-governmental or intergovernmental human rights organisations that competed to protect the rights of detainees. The OHCHR had already made the fight against human trafficking the priority of its work in Bosnia, even if it occasionally criticised the lack of respect for the rule of law when detainees were transferred to SFOR custody. ${ }^{67}$ Other organisations such as the OSCE or the Council of Europe, who played a significant role regarding detentions in Kosovo (see below), showed no ambition to act as accountability holders with regard to SFOR detentions. ${ }^{68}$ Some degree of competition can only be identified within the domestic realm. The newly established Bosnian courts needed to develop a distinct profile in the fresh institutional landscape after the Dayton Agreement and to prove their independent standing vis-à-vis the Bosnian government in terms of a democratic separation of powers and the protection of constitutional rights. The courts decided to do this by criticsing the excess of authority of the international presence and the lack of protection provided by the Bosnian state. ${ }^{69}$ Thus, while on the international level no significant movement advocated for the rights of detainees in Bosnia, the competition among judicial actors nevertheless stimulated attempts at pluralist accountability at the domestic level.

The second condition for pluralist accountability, the implementing actor's vulnerability with regard to human rights demands, remained rather low in this case as SFOR was very successful in keeping its detention practices immune to human rights demands. The Security Council in its Resolution 1031 required the SFOR contributing states to cooperate with the International Criminal Tribunal for the former Yugoslavia (ICTY), which had been established for the prosecution of war crimes. ${ }^{70}$ When detention practices increased after 1997, NATO's cooperation with the court thus provided the argumentative basis for refusing to recognise accountability holders that would monitor and sanction SFOR detention. ${ }^{71}$ As the international community had pressured SFOR to cooperate with the ICTY in arresting war criminals, and with the failure of the international community to hinder the massacre of Srebrenica still in everybody's mind,

\footnotetext{
${ }^{64}$ Amnesty International, 'The Apparent lack of Accountability'.

${ }^{65}$ Sabahudin Fijuljanin v. the Federation of Bosnia and Herzegovina, no. CH/02/12499 (11 January 2003); Bogdan Subodic vs. BiH (23 September 2005); and Dusko Tesic and others vs. BiH (16 January 2005).

${ }^{66}$ Majbritt Lyck, Peace Operations and International Criminal Justice: Building Peace after Mass Atrocities (New York: Routledge, 2009), p. 116.

${ }^{67}$ Colum Lynch, 'U.N. prosecutors giving terrorism evidence to U.S.', The Washington Post (29 May 2002).

${ }^{68}$ Organization for Security and Co-operation in Europe, '10 Years OSCE in Bosnia', available at: \{http://www.oscebih.org/ documents/osce_bih_doc_2011030815040118eng.pdf\} accessed 31 January 2015.

${ }^{69}$ Valerija Galić, 'Separation of Powers and Independence of Constitutional Courts and Equivalent Bodies. Report: Bosnia and Herzegovina', available at: $\{$ http://www.venice.coe.int/wccj/Rio/Papers/BiH_Galic_e.pdf $\}$ accessed 30 November 2014; Constitutional Court of BiH, Decision No. AP 953/05 (8 July 2006), available at: \{http://www.ccbh.ba/eng/odluke/povuci_html.php?pid=59843\} accessed 30 November 2014.

${ }^{70}$ Niccolò Figà-Talamanca, 'The role of NATO in the Peace Agreement for Bosnia and Herzegovina', European Journal of International Law, 7:1 (1996), pp. 164-75.

${ }^{71}$ See the summary of the meeting of NATO defence ministers at North Atlantic Council (8 June 2000), available at: \{http://www.nato.int/cps/en/natohq/official_texts_18203.htm?selectedLocale=en\} accessed 30 November 2014.
} 
nobody dared to question detentions in relation to their compliance with human rights. ${ }^{72}$ SFOR was further able to make itself invulnerable to any human rights demands by invoking security as a counter-norm, and could thus refuse to recognise accountability holders that attempted to monitor and sanction its detentions practices. ${ }^{73}$ Detentions were thus regarded as part of the military task necessary for a successful implementation of the mandate, in contrast to the understanding that prevailed prior to 1997, which considered detentions to be part of a civilian mandate to be fulfilled by the Bosnian authorities. ${ }^{74}$

To sum up, the two operations in Bosnia illustrate the development of pluralist accountability. In the first case, the competitive environment of the OHCHR in Geneva and in Bosnia stimulated the office to develop a distinct profile as an accountability holder $v i s-\grave{a}$-vis the international presence and its involvement in human trafficking. The increasing vulnerability of the UN and its IPTF officers motivated them to recognise pluralist accountability holders. In the second case, to the contrary, there was no competitive environment that could have stimulated external third parties to act as accountability holders for the rights of detainees. Only within the domestic context, there were some elements of competition: Bosnian courts issued decisions on detentions by SFOR to demonstrate their independence and to develop their profile in a newly created legal landscape. Nevertheless, the detaining authorities managed to preserve their invulnerability with regard to human rights demands by framing detentions in the context of an enhanced cooperation with the International Criminal Tribunal for the former Yugoslavia and by invoking the counter-norm of security after 2001. As a consequence, SFOR detentions in Bosnia remained mostly unchallenged with regard to their compliance with human rights standards.

\section{Pluralist accountability regarding UNMIK and KFOR detention practices in Kosovo}

The history of international territorial administration culminated in the transitional administration in Kosovo. Under Resolution 1244, the UN Security Council established the UN Mission in Kosovo (UNMIK) with a mandate that included a wide range of state-building tasks. ${ }^{75}$ In addition to that, the Security Council mandated NATO to deploy a military force, which became operation KFOR. Both operations were equipped with a high degree of authority, which had a direct impact on the rights and lives of individuals. The violation of the rights of detainees was the most direct result of this authority.

Between 1999 and 2005, several types of arrests and detention were carried out by UNMIK and KFOR. As the civilian authority in Kosovo, the UN Special Representative of the SecretaryGeneral issued executive orders to detain arrested individuals who, according to international law, would otherwise have had to be released. ${ }^{76}$ KFOR detentions were, in comparison with UNMIK detentions, much higher in number. More than 3,500 individuals had been detained in extra-judicial detentions between 2001 and 2003 at Camp Bondsteel, a detention facility run by

\footnotetext{
${ }^{72}$ John R. W. D. Jones, 'The implications of the Peace Agreement for the International Criminal Tribunal for the former Yugoslavia', European Journal of International Law, 7:1 (1996), pp. 226-44; Cedric Ryngaert, 'Arrest and detention', in Luc Reydams, Jan Wouters, and Cedric Ryngaert (eds), International Prosecutors (Oxford: Oxford University Press, 2012), pp. 647-99.

${ }^{73}$ The General Framework Agreement for Peace gives us the authority to detain him as long as we deem necessary to continue our investigations, and his detention will continue for as long as we deem it appropriate.' (SFOR Commander Vanier in reaction to complaints against the prolonged detention of Fijuljanin, as quoted by Amnesty International, 'The Apparent lack of Accountability', p. 16).

${ }^{74}$ Lyck, Peace Operations and International Criminal Justice, p. 115.

${ }^{75}$ United Nations Mission in Kosovo, UN doc. UNMIK/REG/2000/38, 'UNMIK Regulation on the Establishment of the Ombudsperson Institution in Kosovo' (30 June 2000); United Nations Security Council, 'Resolution 1244(1999)' (10 June 1999).

${ }^{76}$ Elizabeth Abraham, 'The sins of the savior: Holding the United Nations accountable to international human rights standards for executive order detentions in its Mission in Kosovo', American University Law Review, 52 (2003), pp. 1291337.
} 
the US contingent. ${ }^{77}$ Both UNMIK and KFOR detentions were accused of violating international human rights standards as outlined in the International Covenant on Civil and Political Rights (Art. 9) and the European Convention on Human Rights (Art. 5). Besides the right to information about the reasons for the detention, the right to compensation in the case of illegal detentions and the right to a timely judicial review, especially the lack of the right to habeas corpus, that is, the right to challenge the legality of the detention before a judicial body, prompted major concerns. ${ }^{78}$

Resolution 1244 provided only a very limited accountability framework regarding detentions. The Security Council broadly stated that protecting and promoting human rights was part of UNMIK's main responsibilities and requested regular reports from the Secretary-General, but did not outline specific standards for the mission's own behaviour or for KFOR. ${ }^{79}$ More concrete standards for UNMIK's behaviour were outlined by the Secretary-General, who adopted a bulletin on the 'Observance by United Nations Forces of International Humanitarian Law', which guaranteed the International Committee of the Red Cross (ICRC) access to detention facilities. ${ }^{80}$ For the first time, legal standards were outlined in a binding document that addressed the behaviour of the UN's own personnel. The Secretary-General further determined that ' $\mathrm{i}] \mathrm{n}$ assuming its responsibilities, UNMIK will be guided by internationally recognised standards of human rights. ${ }^{81}$ The general monitoring of human rights in Kosovo was undertaken by the OSCE. ${ }^{82}$ However, these monitoring activities were meant to be directed regarding national actors and former conflicting parties, not the international partner institutions. Vertical sanctioning however was restricted by immunity regulations that applied to UNMIK and KFOR personnel. $^{83}$

This limited vertical accountability regarding detentions spurred strong criticism. Substantial critique came from the Ombudsperson Institution in Kosovo (OIK), which was established in 2000 to review the actions of UNMIK. ${ }^{84}$ The OIK was a result of pluralist accountability exercised by the wider transnational community, in particular the OSCE and the Council of Europe. Although the OSCE had not been mandated to monitor UNMIK or other parts of the international administration in Kosovo, it became an important accountability holder regarding UNMIK's compliance with human rights norms when undertaking detentions. ${ }^{85}$ Together with the Council of Europe, the OSCE established the Ombudsperson Institution in Kosovo, which

\footnotetext{
${ }^{77}$ Council of Europe, 'Kosovo: The Human Rights Situation and the Fate of Persons Displaced from their Homes', Report by Alvaro Gil-Robles, Commissioner for Human Rights for the attention of the Parliamentary Assembly and the Committee of Ministers of the Council of Europe, CommDH(2002)11, Strasbourg (16 October 2002); Organization for Security and Cooperation in Europe, 'Review of the Criminal Justice System (March 2002-April 2003), Protection of Witnesses in the Criminal Justice System' (Mission in Kosovo Department of Human Rights and Rule of Law, 2003). After 2005, officially no detainees were held at Camp Bondsteel any longer (Ombudsperson Institution in Kosovo, 'Quarterly Information Sheet' (Pristina 2005), p. 18).

${ }^{78}$ Amnesty International, 'Document - Federal Republic of Yugoslavia (Kosovo): Amnesty International Calls for an End to Executive Orders of Detention', AI Index EUR 70/017/2001 (3 August 2001); Amnesty International, 'The Apparent lack of Accountability'; Council of Europe, 'Kosovo'; David Marshall and Shelley Inglis, 'The disempowerment of human rightsbased justice in the United Nations Mission in Kosovo', Harvard Human Rights Journal, 16 (2003), pp. 95-146.

${ }^{79}$ United Nations Security Council, 'Resolution 1244', para. 9, $11 \mathrm{j}$.

${ }^{80}$ United Nations Secretary-General, UN doc. ST/SGB/1999/13, 'Secretary-General's Bulletin on the Observance by United Nations Forces of International Humanitarian Law' (6 August 1999).

${ }^{81}$ United Nations Secretary-General, UN doc. S/1999/779, 'Report on UNMIK' (12 July 1999), para. 46; United Nations Mission in Kosovo, UN doc. UNMIK/REG/2000/47, 'UNMIK Regulation on the Status, Privileges and Immunities of KFOR and UNMIK and their Personnel in Kosovo' (18 August 2000).

${ }^{82}$ Organization for Security and Co-operation in Europe, PC.DEC/305, 'Decision No. 305, PC Journal No. 237, Agenda item 2', Permanent Council (1 July 1999); United Nations Secretary-General, 'Report on UNMIK', para. 87.

${ }^{83}$ United Nations Mission in Kosovo, 'UNMIK Regulation 47'.

${ }^{84}$ Florian Hoffmann and Frédéric Mégret, 'Fostering human rights accountability: an ombudsperson for the United Nations?', Global Governance, 11:1 (2005), pp. 43-63.

${ }^{85}$ Marshall and Inglis, 'The disempowerment', p. 138.
} 
was mandated to take complaints and conduct investigations of human rights abuses. ${ }^{86}$ Funded by OSCE member states, the OIK was asked to regularly report to the OSCE Permanent Council. Thus, UNMIK was independently monitored with respect to a concrete set of human rights standards. ${ }^{87}$ When the OIK was turned into a national institution, the Council of Europe pushed for the establishment of a Human Rights Advisory Panel. Contrary to the original proposal, however, the panel remained mainly advisory in its character. ${ }^{88}$

In addition to that, the OSCE office in Kosovo established the OSCE Legal Systems Monitoring Section (LSMS) as a reviewing body with a 'quasi-independent role to monitor the observance of human rights in Kosovo' ${ }^{89}$ OSCE staff investigated conditions of detainees in UNMIK facilities and reviewed the executive orders issued by the SRSG. Moreover, the OSCE LSMS developed a forceful mechanism for normatively sanctioning UNMIK's detention practices through the regular publication of reports and reviews in surprisingly frank language. ${ }^{90}$ It thereby established a link between UNMIK's detention practices and the organisation's legitimacy both from a human rights law perspective and the viewpoint of the governed people.

Why did the OSCE on its own initiative decide to become an accountability holder towards UNMIK in the case of detentions? Within the complex structure provided by Resolution 1244, UNMIK, the EU, and the OSCE operated in an environment of institutional competition for resources and recognition. Therefore, the OSCE in Kosovo had to develop competences that rendered its role distinct from the other organisations. Relying on its mandate from the OSCE Permanent Council, the OSCE Mission in Kosovo used its expertise to sharpen its profile by acting as an accountability holder regarding UNMIK's detention practices. The OSCE LSMS' outspoken criticism, however, also implied the danger of becoming marginalised within UNMIK's policymaking process. ${ }^{91}$ The establishment of an ombudsperson institution was therefore an important means for the OSCE to demonstrate its distinctiveness without mar-

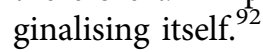

The development of pluralist accountability regarding UNMIK detentions furthermore depended strongly on UNMIK's vulnerability regarding human rights demands. The Special Representative of the Secretary-General defended UNMIK's detention policy by pointing out that there was a trade-off between human rights and security in circumstances of emergency, when 'international human rights standards accept the need for special measures'. ${ }^{93}$ He thus attempted to invoke the counter-norm of security as a shield against claims requesting UNMIK to protect the rights of detainees. After the early successes in establishing a stable security environment in Kosovo, however, it was difficult for UNMIK to uphold this argument credibly, since there was no real emergency any more. ${ }^{94}$ Instead, UNMIK's own priorities of promoting the rule of law

\footnotetext{
${ }^{86}$ Council of Europe, CM/Inf(99)48, 'Council of Europe's Contribution to the United Nations Interim Administration Mission in Kosovo', Committee of Ministers (23 July 1999); United Nations Mission in Kosovo, 'UNMIK Regulation 38'; United Nations Secretary-General, 'Report on UNMIK', para. 90.

${ }^{87}$ Aleksander Momirov, 'Local impact of "UN accountability" under international law: the rise and fall of UNMIK's Human Rights Advisory Panel', International Peacekeeping, 19:1 (2012), pp. 3-18.

${ }^{88}$ Gezim Visoka, 'The "Kafkaesque accountability" of international governance in Kosovo', Journal of Intervention and Statebuilding, 6:2 (2012), pp. 189-212.

${ }^{89}$ Organization for Security and Co-operation in Europe, 'First Review of the Criminal Justice System February 2000-July 2000’ (Legal System Monitoring Section: Pristina, 2000), p. 5.

${ }^{90}$ Organization for Security and Co-operation in Europe, 'Extension of Custody Time Limits and the Rights of Detainees: the Unlawfulness of Regulation 1999/26', Report No. 6 (29 April 2000) (Legal System Monitoring Section: Pristina, 2000); Organization for Security and Co-operation in Europe, 'First Review'.

${ }^{91}$ Clive Baldwin, 'Implementation through cooperation? Human rights officers and the military in Kosovo, 1999-2002', International Peacekeeping, 13:4 (2006), pp. 489-501; Marshall and Inglis, 'The disempowerment', p. 141.

${ }^{92}$ Author's telephone interview with the former Ombudsperson Marek Nowicki, 28 November 2012.

${ }^{93}$ Simon Chesterman, Justice Under International Administration: Kosovo, East Timor and Afghanistan (New York: International Peace Academy, 2002), p. 5.

${ }^{94}$ Author's telephone interview with the former Ombudsperson Marek Nowicki, 28 November 2012.
} 
and justice throughout Kosovo made it increasingly vulnerable to human rights demands. This growing vulnerability eventually led the organisation to recognise pluralist accountability exercised by the OSCE and the Council of Europe and to agree to establish the OIK. By the time the OIK was turned into a purely national institution and lost all competences over UNMIK, however, renewed violence between Serbs and Albanians rendered the provision of security the overarching norm that determined UNMIK's success in Kosovo. ${ }^{95}$ This enabled UNMIK to downsize the Council of Europe's proposal of a Human Rights Advisory Panel after the nationalisation of the OIK.

In the case of KFOR detentions, no comparable system of pluralist accountability evolved, despite the same competitive environment. Like UNMIK, KFOR was confronted with attempts by the OSCE and the Council of Europe to exercise pluralist accountability. ${ }^{96}$ The OSCE argued that KFOR's mandate could only be fulfilled 'through compliance with international human rights standards'. ${ }^{97}$ In its public reports, the OSCE went so far as to demand that 'KFOR cease[d] detentions forthwith and officially renounce[d] its authority in this area. ${ }^{98}$ This was a strong claim from an organisation that was an implementing partner of KFOR. However, KFOR made itself invulnerable to human rights demands by successfully invoking security as a counter-norm. The KFOR commander determined in directive no. 42 of 9 October 2001 that his 'authority to detain is a military decision, not a judicial one. ${ }^{99}$ He argued that extra-judicial detentions were a necessary means for the successful implementation of the security-related aspects of its mandate provided by the Security Council Resolution $1244 .{ }^{100}$ KFOR thus managed to refuse pluralist accountability that would not be under KFOR control. ${ }^{101}$

In sum, the analysis of the two operations in Kosovo has revealed important insights into the conditions for the development of pluralist accountability, in which actors outside of the original delegation relationship enacted accountability functions. The competitive institutional environment stimulated third parties to sharpen their profiles by engaging in standard-setting, monitoring, and sanctioning activities. In the case of UNMIK, the OSCE and the Council of Europe acted as accountability holders and established the Ombudsperson Institution. However, no similar accountability regime evolved in the case of KFOR because KFOR successfully invoked security as a counter-norm and thus made itself invulnerable to human rights demands. This did not work in the same way for UNMIK. The discrepancy between its mandate and its detention practices made it impossible for UNMIK to prioritise security over human rights, at least in the years before the outbreak of violence in 2004. UNMIK's high degree of authority, which effectively allowed the SRSG to run the whole country on its own, increased its vulnerability. Acting like a government entailed certain human rights responsibilities - this was the argument of third parties, who thus forced UNMIK to recognise external accountability holders.

\footnotetext{
${ }^{95}$ United Nations Secretary-General, UN doc. S/2004/348, Report of the Secretary-General on the United Nations Interim Administration Mission in Kosovo (30 April 2004).

${ }^{96}$ Council of Europe, 'Kosovo', paras 97-101; Organization for Security and Co-operation in Europe, 'Review of the Criminal Justice System' (Mission in Kosovo Department of Human Rights and Rule of Law, October 2001); OSCE, 'Review of the Criminal Justice System'.

${ }^{97}$ Organization for Security and Co-operation in Europe, 'Review of the Criminal Justice System', p. 39.

${ }^{98}$ OSCE, 'Review of the Criminal Justice System', p. 34.

${ }^{99}$ COMKFOR directive, Section 2e, as quoted by Amnesty International, 'The Apparent lack of Accountability', p. 21.

${ }^{100}$ See the press releases by KFOR in 2002, available at: $\{\mathrm{http} / / /$ www.nato.int/kfor/docu/pr/2002/08/34-08.htm\} accessed 31 January 2015, and 2004, available at: \{http://www.nato.int/kfor/docu/pr/2004/05/28.htm\} accessed 31 January 2015.

${ }^{101}$ Marcus G. Brand, 'Institution-building and human rights protection in Kosovo in the light of UNMIK legislation', Nordic Journal of International Law, 70:4 (2001), pp. 461-88; Council of Europe, '17th General Report on the CPT's Activities Covering the Period 1 August 2006 to 31 July 2007', Committee for the Prevention of Torture and Inhuman or Degrading Treatment or Punishment (CPT) (Strasbourg, 14 September 2007).
} 


\section{Conclusion}

This article addresses the empirical phenomenon that actions and policies of IOs are increasingly scrutinised by third parties. This is a sign that human rights violations committed by IOs and their partners do not go unnoticed. In this article, I developed the concept of pluralist accountability in order to systematically assess the various standard-setting, monitoring, and sanctioning activities of third parties after allegations of human rights violations by international organisations and their implementing partners have become public. Given the complexity of global governance, this new analytical tool is necessary to understand the accountability dynamics in the absence of traditional, vertical accountability. I argued that two factors contribute to the development of pluralist accountability, namely the competitive environment of third parties and the vulnerability of the implementing actor or the mandating authority.

The empirical analysis provides first empirical insights into pluralist accountability in UNmandated peace operations, an issue area which most pointedly reveals the new intrusiveness of complex global governance for individual citizens. In particular, the analysis has shown how pluralist accountability evolved in the cases of human trafficking in Bosnia and UNMIK detentions in Kosovo and how it failed to evolve in the cases of SFOR detentions in Bosnia and KFOR detentions in Kosovo. The competitive environment stimulated the newly established Bosnian OHCHR to become an accountability holder vis-à-vis the international personnel involved in human trafficking. Similarly, the competition between regional institutions and the UN in Kosovo, in particular, made the OSCE and the Council of Europe push for the establishment of an Ombudsperson Institution and act as accountability holders towards UNMIK. The vulnerability of the implementing actors and the mandating authority with regard to human rights demands in both cases contributed to the recognition of pluralist accountability. In the cases of the violation of the rights of detainees by SFOR and KFOR, to the contrary, competition was rather weak as there were no concurring transnational non-governmental or intergovernmental human rights organisations that competed to promote the rights of detainees. In addition to that, the two operations made themselves invulnerable with regard to human rights demands and thus hindered the evolution of pluralist accountability.

The juxtaposition of the two detention cases demonstrates that the nature and character of human rights violations does not make any difference for the evolution of pluralist accountability. While this might be different for vertical accountability, ${ }^{102}$ the cases did not provide any systematic evidence that certain types of human rights violation, for example, due process rights, are more likely to be responded to by pluralist accountability. Instead, we can see a clear variance in the outcome variable that could not be attributed to different types of rights violations but could be traced back to the two conditions of competition and vulnerability. Furthermore, the analysis has also shown that pluralist accountability is not automatic if vertical accountability is lacking. The evolution of pluralist accountability in all the cases has been independent from the accountability regimes that existed at the outset of the delegation relationships. This should reassure those who consider non-vertical accountability to be only the second-best option and who fear that pluralist accountability might replace important vertical accountability mechanisms.

The argument of this article bears several implications for contemporary IR research, in particular the literature on delegation, IOs, and their institutional environment. Most of the delegation literature so far has focused on the first delegation step, whereby IOs implement the rules for cooperation agreed upon by their member states. ${ }^{103}$ Only recently have researchers started to analyse further delegation steps, where IOs turn from agents into autonomous principals. The results of this study demonstrate the implications of increasing IO authority for

\footnotetext{
${ }^{102}$ Heupel and Michael Zürn (eds), Protecting the Individual from International Authority.

${ }^{103}$ Hawkins et al. (eds), Delegation and Agency; Lisa L. Martin and Beth A. Simmons, 'Theories and empirical studies of international institutions', International Organization, 52:4 (1998), pp. 729-57.
} 
accountability: on the one hand, greater authority has created new dilemmas for accountability; on the other hand, greater authority enables IOs to engage in pluralist accountability vis-à-vis each other. This article thus takes forward the contextualisation of IOs beyond their relationships with member states and speaks to the results of recent research on the interaction of IOs with non-state actors and regional organsations, which demonstrate that the institutional environment in which IOs operate is too important and too varied to be reduced to state-IO relations only. ${ }^{104}$ Pluralist accountability goes hand in hand with the trend of the 'opening up of IOs' in certain steps of the policy cycle. ${ }^{105}$ Recognising them as accountability holders might be one way to ensure IOs interact with outside actors.

Finally, this article paves the way for several strands of future research. First, given that this article focused on pluralist accountability, further research is needed to compare different accountability types. In order to develop an encompassing theory of accountability in global governance, we need to know more about the conditions for each accountability type and the circumstances under which they enhance, compensate, complement, or necessitate each other. Second, the conditions for accountability also need to be examined in other issue areas of global governance. Possible future studies could, for example, look into the accountability regimes that evolved in response to the World Health Organization's emergency governance or new modes of governance as public-private partnerships. Third, this article raises questions regarding the impact of pluralist accountability on the legitimacy of IOs. In the scholarly discussion on IO legitimacy and legitimation, accountability is often advocated as a means to enhance legitimacy. ${ }^{106}$ So far, however, it remains unclear what the impact of different accountability types on legitimacy is. Last but not least, it is important to highlight that pluralist accountability does not imply that there will be fewer human rights violations. This article has analysed the conditions under which pluralist accountability evolves; however, the question of what extent pluralist accountability can effectively constrain the actors held accountable remains outside of the scope of this article. Which accountability type provides the most effective human rights protection therefore remains an open question to be dealt with by future research.

Acknowledgements. I would like to thank Monika Heupel, Thomas Risse, Michael Zürn, and my former colleagues at the WZB 'Global Governance' unit, as well as Jonas Tallberg and his colleagues at Stockholm University for their helpful comments on various drafts of this article. I also thank the two anonymous reviewers for their questions and comments as well as Hannah Bliersbach and Niels van Doesum for their editorial support. Last but not least, my thanks go to my interview partners for their willingness to share their insights.

Gisela Hirschmann is Assistant Professor for International Relations at Leiden University. Previously, she was Junior Professor for Global Governance and Humanitarian Action at the Ruhr University Bochum from 2016-17, and Max Weber postdoctoral fellow at the European University Institute (EUI) in Florence from 2015-17. She received her PhD (Dr. phil.) from the Free University Berlin in 2015 and worked as a research fellow at the Berlin Social Science Research Center (WZB) from 2010-15. Her research interests focus on international organisations, institutional change, human rights, and peace operations, including, most recently, the effects of arts-based peacebuilding.

\footnotetext{
${ }^{104}$ Patricia Nanz and Klaus Dingwerth, 'Participation', in Cogan, Hurd, and Johnstone (eds), Oxford Handbook of International Organizations, ch. 53; Anja Jetschke and Tobias Lenz, 'Does regionalism diffuse? A new research agenda for the study of regional organizations', Journal of European Public Policy, 10:20 (2013), pp. 626-37.

${ }^{105}$ Tallberg et al., The Opening Up.

${ }^{106} J a n$ Aart Scholte, 'Towards greater legitimacy in global governance', Review of International Political Economy, 18:1 (2011), pp. 110-20; Dominik Zaum (ed.), Legitimating International Organisations (Oxford: Oxford University Press, 2013); Michael Zürn, 'Autorität und Legitimität in der postnationalen Konstellation', Leviathan, 40:Sonderband 27 (2012), pp. $41-62$.
}

Cite this article: Hirschmann, G. 2018. Guarding the guards: Pluralist accountability for human rights vialations by international organisations. Review of International Studies 45: 20-38. doi:10.1017/S0260210518000207 